\title{
Article
}

\section{Responses to the primary health care needs of Aboriginal and Torres Strait Islander women experiencing violence: A scoping review of policy and practice guidelines}

\author{
Walker, Natasha, Mackean, Tamara, Longbottom, Marlene, \\ Coombes, Julieann, Bennett-Brook, Keziah, Clapham, Kathleen, \\ Ivers, Rebecca, Hackett, Maree, Redfern, Julie and Cullen, Patricia \\ Available at http://clok.uclan.ac.uk/34825/ \\ Walker, Natasha, Mackean, Tamara, Longbottom, Marlene, Coombes, Julieann, \\ Bennett-Brook, Keziah, Clapham, Kathleen, Ivers, Rebecca, Hackett, Maree \\ ORCID: 0000-0003-1211-9087, Redfern, Julie et al (2021) Responses to the \\ primary health care needs of Aboriginal and Torres Strait Islander women \\ experiencing violence: A scoping review of policy and practice guidelines. \\ Health Promotion Journal of Australia, 32 (2). pp. 40-53.
}

It is advisable to refer to the publisher's version if you intend to cite from the work. http://dx.doi.org/10.1002/hpja.417

For more information about UCLan's research in this area go to http://www.uclan.ac.uk/researchgroups/ and search for <name of research Group>.

For information about Research generally at UCLan please go to http://www.uclan.ac.uk/research/

All outputs in CLoK are protected by Intellectual Property Rights law, including Copyright law. Copyright, IPR and Moral Rights for the works on this site are retained by the individual authors and/or other copyright owners. Terms and conditions for use of this material are defined in the policies page. 
1 Responses to the primary health care needs of Aboriginal and Torres Strait Islander women experiencing violence: A scoping review of policy and practice guidelines

Short title: Response to women experiencing violence

6 Authors

7 Ms Natasha Walker MPH, LLB

8 Associate Professor Tamara Mackean MBBS, MPH, FAFPHM

9 Dr Marlene Longbottom PhD

10 Dr Julieann Coombes $\mathrm{PhD}$

11 Ms Keziah Bennett-Brook

12 Professor Kathleen Clapham $\mathrm{PhD}$

13 Professor Rebecca Ivers PhD

14 Professor Maree Hackett PhD

15 Professor Julie Redfern $\mathrm{PhD}$

16 Dr Patricia Cullen PhD

\section{Author's Institutional Affiliations}

19 Ms Natasha Walker, School of Public Health \& Community Medicine, UNSW, Sydney, 20 Australia; The George Institute for Global Health, Sydney, Australia, UNSW; School of 21 Medicine and Public Health, University of Newcastle, Newcastle, Australia.

22 Dr Tamara Mackean, The George Institute for Global Health Sydney, Australia, UNSW;

23 Southgate Institute for Health, Society and Equity, Flinders University, Adelaide, Australia 24 Dr Marlene Longbottom, Ngarruwan Ngadju: First Peoples Health and Wellbeing Research 25 Centre, University of Wollongong, NSW; Australian Health Services Research Institute, 26 University of Wollongong

27 Ms Julieann Coombes, The George Institute for Global Health, Sydney, Australia, UNSW

28 Ms Keziah Bennett-Brook, The George Institute for Global Health, Sydney, Australia, 29 UNSW

30 Professor Kathleen Clapham, Ngarruwan Ngadju: First Peoples Health and Wellbeing 31 Research Centre, University of Wollongong, NSW; Australian Health Services Research 32 Institute, University of Wollongong

33 Professor Rebecca Ivers, School of Public Health \& Community Medicine, UNSW, Sydney, 34 Australia; The George Institute for Global Health, Sydney, Australia, UNSW 
35 Professor Maree Hackett, The George Institute for Global Health, Sydney, Australia,

36 UNSW; Faculty of Medicine, UNSW, Sydney, Australia; The University of Central

37 Lancashire, Preston, UK

38 Professor Julie Redfern, Westmead Applied Research Centre, University of Sydney; The

39 George Institute for Global Health, Sydney, Australia, UNSW

40 Dr Patricia Cullen, School of Public Health \& Community Medicine, UNSW, Sydney,

41 Australia; The George Institute for Global Health, Sydney, Australia, UNSW; Ngarruwan

42 Ngadju: First Peoples Health and Wellbeing Research Centre, University of Wollongong,

43 NSW

44

45 Acknowledgements

46 We thank Waminda South Coast Women's Health and Welfare Aboriginal Corporation,

47 Yerin Aboriginal Health Service, Illawarra Aboriginal Medical Service, Katungul Aboriginal

48 Corporation Community \& Medical Services for their support and collaboration as research

49 partners in the First Response project.

50

51 Funding Disclosure

52 This study was funded by the Lowitja Institute and The George Institute for Global Health.

53 Patricia Cullen is funded by a NHMRC Early Career Fellowship, Marlene Longbottom by

54 Vice Chancellor Aboriginal Postdoctoral Research Fellow, Rebecca Ivers by an NHMRC

55 Senior Research Fellowship, Maree Hackett by a National Heart Foundation Future Leader

56 Fellowship \#100034

57

58 Conflict of Interest

59 The authors declare no conflict of interest. 